\title{
Fashion and the Social Construction of Femininity in North Korea
}

\author{
Bronwen Dalton \\ Kyungja Jung* \\ Jacqueline Willis \\ University of Technology Sydney
}

\begin{abstract}
In this paper we argue that North Korea's socioeconomic transformation has had a profound and yet under-appreciated impact on the social construction of femininity. Drawing on 45 indepth interviews with North Korean refugees, interviews with regular visitors to North Korea and NGO workers, and our own field notes from trips to North Korea, we analyse changes over three discernible (yet overlapping) economic periods: the 1960s-90s pre-famine period; the mid-1990s to late 2000s grassroots capitalism era; and the current Kim Jong Un period of quasi-capitalism. As dress is a discursive daily practice of gender, we focus on the practice of femininity as shown through North Korean women's fashion choices. We argue that images of women in state propaganda have been shaped primarily by male leaders, but norms of femininity have shaped, and also been shaped by, women themselves. That is, the recent trend for North Korean women to dress in hyper-feminine styles can be explained in terms of women remaking themselves and planning their future lives.
\end{abstract}

\section{KEYWORDS}

North Korea; North Korean Women; transitional economy; women's status; marketisation; femininity; fashion

\section{Introduction}

Important changes are taking place inside North Korea. The ongoing collapse of the command economy, the emergence of capitalism, increasing exposure to foreign pop culture and the growth of a new moneyed elite are influencing the construction of femininity in ways that depart from earlier state prescribed and policed ideals. This is evident from examining the role of women and the social construction of femininity over three discernible (yet overlapping) economic periods: the 1960s-1990s pre-famine period; the mid 1990s to late 2000s grassroots capitalism era; and the current Kim Jong Un period of quasi-capitalism.

We argue that in the pre-famine period the economy was focused on mass production to achieve industrialisation. While women were significant participants in the economy, the statepromoted feminine ideal of revolutionary mother, devoted to serving the state by producing children to be future loyal and disciplined workers, prevailed. In the mid 1990s, in response to economic collapse and widespread food shortages, a form of grassroots capitalism emerged and many women established small market stalls or founded small businesses. For the first time, women had increased mobility and became the family breadwinner, assuming a modicum of economic power. Under the Kim Jong Un regime, the state has become more adept at factoring market development into its political-management strategies, and the market economy has matured.

In this context, a new, richer type of entrepreneur has emerged - the so-called "masters of money" or donju. Women are still engaged in small-scale trading, but the vast majority

*CONTACT Kyungja.Jung@uts.edu.au 
of donju are male. In this increasingly materialistic, consumerist and male-dominated economy, the trend for women to appear in fashionable clothing, wear make-up and undergo basic cosmetic procedures has become widespread. Embracing new styles of dress and personal grooming can be viewed as a rational, and even necessary, strategy for women looking to gain power and distinguish themselves by seeking coveted social rewards - namely, a white-collar job and a socially desirable marriage. The social construction of North Korean femininity over these three periods is thus a case of women not only being shaped by, but also shaping the social construction of femininity, processes that have broadened what it means to be a woman in North Korea, from mere reproducers of workers to reproducers of social status. The paper is informed by 45 interviews with North Korean refugees, fieldtrips to North Korea and analysis of primary and secondary sources over these periods.

In this paper we analyse how North Korea's socioeconomic transformation has influenced the social construction of femininity. In each period we explore how changes in the economy and society have influenced gender roles and the social construction of femininity. In particular, we focus on the practice of femininity as shown through North Korean women's fashion choices, as dress "is a discursive daily practice of gender" (Huisman \& Hondagneu-Sotelo, 2005, p. 44). We argue that while images of female citizens in state propaganda have been shaped primarily by male leaders, norms of femininity have shaped, but also been shaped by, women. In particular, the current widespread trend for North Korean women to dress in hyper-feminine styles is an agentic process of remaking themselves and planning their future lives.

\section{Marxist and Feminist Perspectives on the Socioeconomic Basis of Gender Relations and the Social Construction of Femininity}

Marxists and feminists have both developed theories concerning the influence that the interaction of social and economic forces has on the construction of gender relations and femininity. Marxist approaches argue that male dominance is a creation of capitalism, while feminist approaches argue that capitalism is one expression of male dominance. However, rather than engaging in the debate over which came (or comes) first - sex or class - or attempting to synthesise feminism and Marxism as to do so would fail to recognise the depth of the antagonism or the separate integrity of each theory, we stress that far from being separate constructs, sex/gender and class are intersectional and mutually constitutive. Thus, rather than treating feminism and Marxism as a binary, we argue that in the fullness of time, the North Korean case may well challenge the binary between the two. At any rate, as theories of drivers of power and its uneven distribution, both feminism and Marxism provide useful theoretical lenses through which we can examine the social construction of femininity in North Korea.

Extending Karl Marx's argument that human nature is socially constructed and historically shaped, gender relations and related notions and practices of femininity can also be understood as socio-historical. For Marxists, the economy exists as the greatest shaping influence in society, with each society shaped around its economic system (see Cohen, 1978). From this perspective, a particular type of economy also shapes specific types of gender relations and even sexual culture. For example, in England, Marxists argue that in the nineteenth century a sexual culture took shape organised around procreation in marriage, as sexualities were at odds with the need for disciplined productive workers. With the emergence of a new consumer economy in the twentieth century, the Victorian emphasis on privacy, self-control, and desexualisation of the body and intimacy was weakened by a process wherein capitalists tied feminine ideals to higher levels of conscious consumption (Seidman, 2005, p. 7). We argue 
that gender relations and the social construction of femininity in North Korea are equally tied to the state's economic system, but that profound new social forces have also been at play.

Feminists do not only view gender as shaped by the economy, but give greater weight to its social foundations. Femininity is a form of social identity governed by a set of norms of behaviour, and thus is socially constructed. As Simone de Beauvoir (1952, p. 267) argues, "one is not born, but rather becomes a woman". Entwistle (2001, p. 33) elaborates on how social conventions relating to the presentation of the body, including dress, carry social meaning, maintaining that they are "the means by which bodies are made 'decent,' appropriate, and acceptable within specific contexts".

Adherence to the norms of femininity can signify affluence and thus class. Throughout history women have been socialised to embody the feminine ideal of the relevant era and place. As Langland (1995, p. 56) notes, in Victorian England, this socialisation presented ideals relating to appropriate dress at various times throughout the day, presentation of self and belongings within the home, and even extended to expectations of sociality, including engagement in charity work. Socialising agents included texts such as Etiquette for Ladies, an 1837 guide that Langland (1995) argues aimed to reproduce normalised hegemonic constructions of gender that reinforce power structures and class and gender differences. Delamont (1978, p. 145) notes that gender expectations remained even after women entered the education system, referring to this as a practice of "double conformity", where their educators had to uphold principles of decent feminine behaviour. Drawing on such insights, it can be argued that a woman's class, status and overall propriety are determined by the degree to which her behaviour and appearance meet the idealisations of her gender.

But why do women willingly comply with these male-defined expectations of beauty and femininity? Is such conformity a case of women's "false consciousness"? This has become a central concern of gender studies and is addressed in a growing body of literature that argues that to view women as passive is to overlook both socioeconomic context and their potential for agency (Burton, 1992; Choo, 2006; Teng, 1996). Bordo's (2003, p. 262) insight regarding the "self-normalization to everyday habits of masculinity and femininity" is important in this regard as, with respect to the latter, it acknowledges that a woman's appearance and embodiment of femininity are shaped by both her own subjectivities and agency, and by socialisation and social expectation (see Entwistle, 2001; Tyner \& Ogle, 2009, for further discussion of this dual construction of femininity). In this vein, the authors claim that, in North Korea, while the economy and social expectation matter, women still have agency.

These insights inform a growing body of literature on hyper-femininity that Praechter (2006, p. 254) defines as "a particularly exaggerated, emphasized and ideal performance of femininity". Contributors to this literature argue that conforming to feminine ideals is a way in which women protect their agency. The phenomenon of hyper-femininity has mostly been studied in contemporary Western middle-class contexts, particularly within youth cultures, but some ethnographic research has examined the role hyper-femininity plays in emigration. Findings from these studies show how the notion of hyper-femininity may be usefully generalised to address the various ways in which women of different backgrounds make use of gender symbolism to establish claims to social worth and respect. In a study on former USSR women migrating to Alpinetown (in northern Italy) and employed as live-in careworkers, Cvajner (2011, p. 356) argues that hyper-femininity plays a compensatory role, "allowing these women to detach themselves from conditions they regard as degrading". Gal and Kligman (2000) argue that in the context of Eastern European post-socialist countries, younger Central European 
women are more likely than older women to attend to their appearance as a sexualised feminine body represents successful modernisation and progress. Choo (2006, p. 591) describes how North Korean women resettling in South Korea proactively seek to overcome discrimination by making a conscious effort to "remove the 'North Korean dust' that clings to and distinguishes the body's appearance" by ridding themselves of ethnic markers, including wearing expensive designer clothes, in order to adapt to South Korean gender ideals.

Applying the arguments of Tyner and Ogle (2009, p. 104) to the North Korean context, we contend that it is particularly important to "transcend the oppressor versus oppressed model" when discussing North Korean women. This is because the depiction of North Korean women as victims and lacking agency has come to dominate the discourse. On reportage of North Korean women, Choo (2006) discusses the "rescue ideology" whereby North Korean women are depicted as desperate and helpless, and as victims of sex trafficking and various forms of male-perpetrated violence (see Lintner, 2007; Muico, 2005). We echo Choo's (2006) position and argue that this common portrayal of North Korean women presents an oversimplified and unrealistically passive construction of North Korean women, and that such rendering of their experience ignores the complex ways in which North Korean women, both at home and abroad, exercise their agency.

\section{Methodological Approach and Description of Participants}

From 2006 to 2016, through field work in July 2006, January 2008, September 2014, May 2015 and January 2016, we conducted 45 in-depth interviews with refugees (including three males). All interviewees had resettled in South Korea, with the exception of one man who was living in a third country.

The majority (23) of those interviewed left North Korea between 2010 and 2015, with 16 arriving in South Korea between 2001 and 2009 and five between 1994 and 1999. Twentythree interviewees were in their twenties and thirties at their time of departure, with nine in their forties, five in their fifties, four in their sixties and two in their teens. As most participants interviewed during the first two fieldtrips left North Korea between the mid-1990s and the early 2000s, the data collected from these trips was used to analyse gender relations and the construction of femininity during the Kim Jong Il period. Similarly, as many of those interviewed between 2014 and 2016 left after Kim Jong Un took power in December 2011, these later interviews shed light on the shifts that occurred following the death of Kim Jong Il, as well as comparisons and contrasts to the Kim Il Sung era.

In terms of geographic representation, the majority of participants were from the north-eastern provinces of North Korea with 26 from North Hamgyeong province. Nine were from Yanggang province, three from South Pyeongan, and two from South Hamgyeong, while Jagang and North Hwanghae provinces were each represented by a single participant. Only three interviewees were from North Korea's relatively privileged capital of Pyongyang.

Data from refugee interviews have been augmented by data from interviews with NGO workers and regular visitors to North Korea, and field notes collected by Dalton during two seven-day trips to North Korea in 2014 and 2015. ${ }^{1}$ Dalton visited schools, theatres, hairdressers, restaurants, a department store and other public spaces in Pyongyang, Hyesan and Gaeseong for observation purposes. 
[Insert Table 1 North Korean Defectors Interviewed.docx about here]

\section{Revolutionary Mothers (1960-90s)}

From the 1960s women in North Korea were encouraged to participate in the economy. In 1946 Kim II Sung (1946, p. 354) pronounced: “[W]omen ... can achieve complete emancipation only if they strive with no less devotion and awareness than men to solve the problems arising on the productive fronts of the factories and countryside". During the Kim Il Sung era the state progressively mobilised women for its economic purposes and, by 1967, women accounted for almost half of the total workforce (Hunter, 1999, p. 95).

While state propaganda promised women equal opportunity, status and remuneration, the division of labour was gendered. The mobilisation of female labour was partly motivated by a goal to move male labour out of light industries and into the heavy industries (Lankov \& Kim, 2014). Women were typically restricted to "low status, physically arduous and dirty jobs" (Smith, 2015, p. 279) that were considered appropriate for their gender, including agriculture, education, hospitality, low-level clerical jobs and health care, while men dominated the higherpaid occupations in mining and heavy industries, government, engineering, and trade and finance (Anderson, 2016).

Women achieved some formal equality under the Law on the Equality of the Sexes of 1946. Yet unlike during the 1960s Great Cultural Revolution and 1970s Anti-Confucian Campaign in China, or in the Soviet Union in the late 1920s, no law or campaign in North Korea ever explicitly or directly criticised domesticity or women's place in the home (Kim, 2013, p. 178). North Korea's patriarchal nature was also buttressed by women's dependence on the state for food and social services, particularly in the pre-famine period (Jung \& Dalton, 2006). There have been various inconsistencies between North Korea's supposedly progressive gender equality laws and the regime's view of women's primary role as wives and mothers. One of the participants in this study, "Eun", describes how this socialisation process begins at an early age:

When I was in elementary school I had a male teacher who taught revolutionary history. He would say to us girls, girls are only worth fifty percent whereas boys are worth one hundred. We always confronted him ... then he would say that [North Korean] society referred to boys as people, but to us only as "girls".

For this reason, North Korea has been described as a "patriarchal socialist state" (Lee, 2005), wherein husbands are considered the head of the family.

Ending women's confinement to traditional roles was thus limited to making their labour available to the regime. Domestically they were to uphold the feminine ideal of a subservient and selfless mother. This expectation seems to be equally shared by women at all levels of society. Our interviewee "Seol" reflected on this period:

Even women who went to good universities ended up getting married off and spending the rest of their lives looking after their children at home. That's the kind of society North Korea was. 
On 16 November 1961, in a speech at the National Meeting of Mothers, Kim Il Sung (1971, p. 25 ) criticised women in the past "who went about dressed to kill and wearing fancy hats"; he claimed that "these women have been removed from their posts and the ranks of the Women's Union". He continued: "How can Women's Union work be conducted by the so-called enlightened women if they are ignorant of the factory and rural life and only know how to apply make-up and hair curlers? To tell the truth, it is not so essential to have curly hair and wear pretty dresses" (Kim, 1971, p. 28). In Kim Il Sung's view, expressions of femininity such as "make-up", "hair curlers", "pretty dresses" and "fancy hats" were disruptive of both physical and ideological discipline and needed to be controlled.

Nevertheless, unlike other socialist regimes that embraced masculine clothing as a symbol of revolutionised women, the state promoted both the traditional dress and a feminised military uniform. On femininity, Kim Il Sung (1989, p. 5) pronounced that "women should not solely focus on their liberation, rights, and equality and forget about the traditional feminine beauty and virtue that typically defined the Korean women ... women should be feminine after all".

These seemingly contradictory statements exemplify the state's expectations that women fuse the personas of selfless mother, hard worker and ethnically and ideologically pure subject. For decades the embodiments of the feminine ideal were Kim Il Sung's mother Kang Ban-seok, and Kim Il Sung's first wife and mother of Kim Jong Il, Kim Jeong-suk. In newspapers, poems, songs and slogans these two women are eulogised as both passionate revolutionary fighters and the epitome of self-sacrificing and loving mothers. Kang Ban-seok consistently appears in state iconography in native Korean dress, the joseonot, an ethnically distinctive garment made of jeogori (short jacket) and chima (long, wide skirt), and with traditional hairstyles. This depiction served to reinforce femininity as tied to the traditionally subservient "purely Korean" selfless mother and ideals of womanhood, in line with the "wise woman, good wife" ideal of 1920s Korea (Anderson, 2016, p. 24). Kim Jeong-suk is depicted in a feminised military uniform, with a skirt and a distinct waistline. Her image came to symbolise the role of women in the revolution. Kim (2011, p. 161, pp. 178-179) argues that these two styles of dress are "coproduced in a symbiotic realm of feminine ideals" that emphasises the expectation that women "fulfill a binary set of duties within the domestic and public realms". She argues that "If Kang Ban-seok was the mother who epitomized Korean women's virtue in the domestic realm, Kim Jeong-suk was the archetypal model for the 1970s women who negotiated domestic activities with public ones, including military struggle" (Kim, 2011, p. 178). The ideal North Korean woman is one who in body and mind is able to successfully negotiate "the dual values of domestic femininity and socionationalist femininity” (Kim, 2011, p. 177).

[Insert Photo 1 revolutionary-Kim Jeong-suk.jpg about here]

Caption: Mural in the Pyongyang subway depicting Kim Il Sung and his first wife and mother of Kim Jong Il, Kim Jeong-suk. Photograph by Lesley Parker

In daily life, styles of dress inevitably departed from these ideals. Working women mostly wore state issued clothing made of the stiff and hard-to-dye vinalon, the country's invention and referred to as the "cotton of self-reliance" (chuch'e üi som). Vinalon was used extensively in the making of clothing, "to make everything from suits, shirts, work clothes, and dresses, to innerwear, sweaters, towels, and socks" (Kim, 2014, p. 821). However, although the state was meant to provide citizens with two sets of both work and everyday wear on a biennial basis, 
supply was unreliable and obtaining basic clothing such as shoes and socks was an "immediate concern" (Oh \& Hassig, 2004, p. 57).

Proximity to the feminine ideal was more likely to be expected of women in privileged working roles such as waitressing in international hotel restaurants. Sonia Ryang (2000, p. 339) writes of her observations of women in the service industry during her visit to Pyongyang in 1984:

Women in the service industry in the capital Pyongyang were willing to conform to the image of frailty and prettiness...These women on the whole were slender and long-haired (mostly permed), wore heavy make-up, and smiled profusely.

Ryang (2000, p. 339) notes, however, that in a North Korean mining town she visited in the early 1980s, women wore trousers and buttoned-up tops, approximating "the Soviet emancipée type".

According to our interviewees, for the most part, consumerism and keeping up with fashion did not seem a preoccupation. One interviewee, "Joo", stated that: "Ordinary people didn't buy a lot of different clothes because everyone was so busy working. Whether a person dressed well, or didn't, it didn't matter". "Seol" reflected on her attitudes towards her own appearance during this period:

I never thought once about becoming prettier... My understanding of beauty was not based on wearing stylish clothes or having good looks, but rather having proper thoughts and a proper life... That's what I thought was beautiful... Because they educate you like that ... that was my life.

\section{Women-led Grassroots Capitalism (Mid 1990s to Late 2000s)}

The period between 1991 and 1996 was one of crisis and upheaval for North Korea, brought on by the fall of the Soviet Union in 1991, a series of natural disasters, and government mismanagement. During this time the North Korean economy contracted by approximately 30 per cent (Jung \& Dalton, 2006, p. 741) and the North Korean people endured a devastating famine in which between 600,000 and a million people succumbed to famine-related illness (Natsios, 2010; Haggard \& Noland, 2007).

The process of marketisation in North Korea has been distinct in two respects. While other communist countries introduced a market economy from above, in North Korea, marketisation occurred in the absence of any decisive or consistent institutional reforms and instead occurred as a way of coping with economic and food shortages (Haggard \& Noland, 2005; Haggard \& Noland, 2007). As "Lim" explains, "when the PDS failed, and I lost my job at the factory, I came to a realisation then and there that I could only survive by working in the markets". Secondly, women played a major role in this marketisation process. Reports from North Korean refugees state that between 76 per cent (Haggard \& Noland, 2013, p. 54) and 80 per cent of market traders are women (Lankov \& Kim, 2008, p. 68). Thus, at this time, women's financial contribution to the household was no longer regarded as auxiliary, and for many families, women became the main breadwinners. Among those interviewed for this study, 41 of the 42 female refugees had been directly involved in market trading in North Korea and 39 said that they had been the primary breadwinners for their families. 
In this context, our interview data suggest that women's attitudes toward their husbands are changing. Our interviewee "Kyung" observed that there are a number of popular colloquial expressions that refer to men as "useless", such as describing men as: "a guard dog who stays at home all day" and "a light bulb in the day". Another interviewee, "Hong", stated that "if they [husbands] stand, they are like statues, if they sit, they are like a torso, and if they lie down, they are like a corpse". "Ban" commented that husbands frequently became the subject of jokes:

We women in the markets would joke, "If there was anyone who would buy my husband I would be more than happy to sell him".

Separation and divorce rates have risen markedly over the last 30-40 years, leading to a significant increase in the number of female-headed households (widowed, divorced and single women) (Jung \& Dalton, 2006). Twenty-three of the 42 women interviewed for this study were widowed, divorced or separated when they were in North Korea. In line with these changes, women are reportedly also less inclined to marry or have children (Jung \& Dalton, 2006). As Lim (2004, pp. 94-95) explains, "greater economic independence has allowed many women to leave violent or unfaithful husbands".

There is also some evidence that the preference for sons has diminished, with parents seeing daughters as more likely to reap benefits in the emerging economy. Our interactions with North Korean refugees suggest that most people prefer to have daughters, especially since the famine. "Lim" describes this trend as "daughter fever" and believes that this is due to parents' recognition that females are more likely to make money. Another interviewee, "Ban", confirmed this emerging preference for daughters when she said:

In North Korea now, people have children in the hope that they will have daughters. Sons are no good... Also, men have to serve in the army. At least women can work in the markets. Men can't - they have to go to their official posts.

Female market participation, however, comes with significant downsides. All of the women interviewed for this study said that they still performed most of the domestic work as well as having to work outside the home, which often entailed physically intensive work and long distance travelling. "Lee" said:

I worked harder than anyone, to earn money. I could barely sleep, waking up at 5 am to prepare meals, send my husband off to work, and clean up my baby. We didn't even have disposable nappies in North Korea, only cloths that had to be laundered daily. So, I would wash my baby's clothes by hand - there was no washing machine - and go out to the markets. I even had livestock - three pigs that I had to look after.

Other responses suggest that this is not always the case and that the expectation that women do all of the housework is contested. According to "Seol":

As the rations waned, women took more initiative and went out and worked.

The men would stay home and cook. I think that women's and men's roles 
swapped over. So even though men are, by tradition, higher in rank, as the head of the household or whatever ... the women were just too busy to do housework.

In addition to their inequitable dual economic and domestic responsibilities, female traders have become a target of regime control and corruption (Haggard \& Noland, 2012). All of the participants in this study recalled having to bribe officials. "Kang", who was involved in a range of trade activities involving herbs, animals, petrol, grains, and human trafficking and brokering, said she had been arrested 23 times and served two terms in jail. All of those interviewed indicated that dealing with officials was the greatest challenge to successfully running a business in North Korea.

\section{Femininity and Fashion in the Grassroots Capitalist Era}

As Lankov (2014, p. 89) points out, ironically it was at this time of economic crisis that North Koreans began to dress well. The public distribution of clothes ceased in the early 1990s, prior to the collapse of the food distribution system. Since that time North Koreans have become accustomed to buying their own clothes.

Many former female traders we interviewed said that they preferred more functional dress, such as wearing trousers, which offered better mobility, including allowing them to more easily ride bicycles. On fashion at this time "Lim" said:

North Korea had a lot of limitations when it came to trends. Foreign things were banned. People wouldn't wear clothing that had English writing on it. So the trendiest thing in North Korea was the Kim Jong Il jacket, and after that, Kim Jong Il's signature general's suit. But for day to day we had to wear clothes that allowed us to carry our goods on the backs of our bicycles.

Figure 2 below, a photograph taken on a warm September day in rural Yanggang province, shows a woman dressed to accommodate the weather and the physical demands of carting goods to market.

[Insert Photo 2: Breadwinners Haul about here]

Caption: In the countryside of the rural Yanggang province. Photograph by Sora Shi

\section{Kim Jong Un Period of Quasi-capitalism (2011-)}

In the Kim Jong Un era the North Korean economy is shifting from a grassroots to a quasicapitalist economy. Tudor and Pearson (2015, p. 19) argue that nearly all North Koreans lead an "economic double life", supplementing insufficient state-supplied rations and wages of as little as "a few dollars a month" (Tudor \& Pearson, 2015, p. 35) with economic activities. Analysis of satellite imagery from 2003-2014 graphically demonstrates the extent to which domestic markets have been expanding in both size and quantity (Silberstein, 2015).

Victor Cha (2012, p. 442) argues that "the big difference in North Korea between its first power transition in 1994 and the one in 2012 is the existence of a market mentality". All participants interviewed for this study observed that on the surface North Korea is a socialist country, but beneath the surface non-socialism (interviewees often used this term instead of 
"capitalism") is operating. When asked how people in North Korea should live their lives, "Lee" said:

It's all about a person's ability to make money... We are socialist on the surface, and non-socialist on the inside. North Korea prides itself on the fact that everything is free ... but even at the hospital, they serve the wealthy before they treat the poor ... [and] mothers tell children not to go to school, because teachers keep asking them to pay for various things.

Various top-down measures are perhaps partly behind the maturation of the market-driven economy. Accounting for the extent to which marketisation has evolved and matured under Kim Jong Un, Lankov (2015) argues that there are signs Kim Jong Un is quietly pursuing a set of limited market-oriented reforms, including the " $28^{\text {th }}$ June Measures" of 2012 . These began to transform North Korean agriculture and allow more private family-based farming. The " $28^{\text {th }}$ June Measures" also experiment with an independent accounting system that allows managers some discretion around purchasing, as well as the distribution, hiring and remuneration of workers. As Lankov (2015) notes, this represents a significant departure from Kim Jong Il's strategy.

This widespread engagement in market activity is creating a moneyed elite, known as the donju (literal translation, "masters of money"). Given that strong connections and political and social capital are necessary to source significant amounts of capital and circumvent predatory corruption and punishment, the vast majority of donju are men. Women remain in the markets, but operate simpler, safer businesses that deliver slimmer profit margins.

\section{North Korean Women's Fashion under Quasi-capitalism}

The donju might constitute the top "one per cent" (Fifield, 2016); however, a larger class of people with some disposable income has also emerged. As commerce has been brought into daily life, including into leisure, recreation and entertainment, people are frequenting restaurants and buying all kinds of household appliances (Lankov, 2014, pp. 91-93). Conspicuous consumption is also affecting fashion.

In this context, the wife of North Korea's leader, Ri Sol-ju, has become a visible and influential trendsetter. North Korea's state news agency has featured Ri at various public events, wearing high heels and form-fitting stylish clothes. Surprisingly, on one occasion, she was not even wearing the dual portrait lapel pin that carries the images of former leaders Kim Il Sung and Kim Jong Il. Instead she has sported a variety of designer brooches. It would seem that North Korea is continuing the tradition of depicting women connected to the Kim dynasty as representations of feminine citizenship ideals, although Ri Sol-ju represents a clear departure from traditional representations. ${ }^{2}$

Other North Korean female fashion icons include the women in North Korea's most popular girl band Moranbong. Their short skirts, high heels and sequined clothing have inspired or reinforced the trend among women to wear brighter, better-cut clothing.

During two trips to North Korea (in 2014 and 2015), Dalton observed how North Korean women are embracing a diverse array of fashionable clothing either brought in from China or sewn in small North Korean factories. Many women seem to prefer logo-emblazoned goods and anything that can incorporate sequins and diamantes, including tops, hairpins and even the 
soles of their high-heeled shoes. High heels are de rigueur. One rarely sees a woman under 50 not wearing pumps of some kind. According to "Ha", "Everyone, like my friends, would wear high heels and pretty shoes and I wanted to wear them, too. So I would buy them with my money".

This "capitalist" hyper-femininity appears to have gained currency beyond the capital, and is evident on the streets of all North Korea's major cities. Acquiring fashionable clothes for some seems a priority: "As soon as I earned some money the first thing I'd do is buy some clothes," said "Lim". There are reports about how tailors across North Korea are producing a huge range of counterfeit designer clothing. The Gangsun area in Nampo City is becoming well known for this, and North Korea's local markets do a brisk trade in earrings, handbags, clothing and make-up from China and South Korea (Radio Free Asia, 2013).

Basic cosmetic procedures are also being performed across the country. All 23 female interviewees who had left North Korea after 2010 had had double eyelid surgery operations in North Korea (only one of them in Pyongyang). "Ha" from South Pyeongan province stated that: About 50 per cent of my friends had their eyelids done... It's banned at schools. So people try to do it covertly. If they get caught, they have to endure sessions of self-criticism. Most students do their eyelids as soon as they graduate from high school.

According to "Hahm",

It's not like here in South Korea where cosmetic surgery is large-scale... North Korea doesn't have that. There are double eyelid and eyebrow/eyeline tattoo treatments. But nothing like (touches her face with her hands)... Because there isn't such a concept.

\section{Influence of South Korean Culture on North Korean Women's Fashion Choices}

With the markets has come increased access to information about the outside world, and especially popular is the consumption of South Korean popular culture. North Korean women are regular consumers of South Korean television shows, and dramas in particular (Kang \& Park, 2011), which have played a significant role in influencing their fashion choices. "Kyung" observed that:

Because people watch a lot of dramas now ... bags are in fashion... My younger sister was watching a drama and she saw a pretty bag... She bought one and gave it to my daughter, saying, "Use this when you go out".

South Korean fashion and other products have come to carry the greatest social cache. According to "Ahn",

South Korean products are very popular. Many Korean products have made their way past the border. At Dumangang, all the tags and labels would be removed first. And then they would enter the North Korean market stream ... but we can't say that they are from South Korea. We say Hong Kong, or Taiwan... But in truth, everybody knows that they are from South Korea.

"Kang" noted that "If people say that something is trendy in South Korea then people will spend any amount of money to wear that design". 
But, as shown in Figure 3, North Korean women's fashion choices are closer to those seen in China than in South Korea. One Australian tour operator and regular visitor to North Korea noted the Chinese influence on North Korean styles:

I've noticed North Korean women's fashion become more and more varied over the past few years. The Chinese influence is obvious. The preference is for markedly feminine clothing featuring ribbons, lace, sequins etc. Such outfits are rarely worn without a pair of high heels (Sigley, personal communication, 14 July 2016). ${ }^{3}$

The most common "look" skirts, dresses and hair pins adorned with sequins and lace. Femininity in North Korea thus aligns with Praechter's (2006, p. 254) concept of hyperfemininity, as "a particularly exaggerated, emphasized and ideal performance of femininity". Figure 3 shows a woman out and about in the streets of Pyongyang.

[Insert Photo 3 status-funfair-style_28199419001_o.jpg about here]

Caption: Dressed for success: A young woman visiting Fun Fair Pyongyang. Photograph by Lesley Parker

\section{"Getting a Little Rebellious": Pushing the Fashion Boundaries}

Under the current regime, feminine ideals and means of conformity, particularly in terms of dress, have entered a state of flux, emboldening women to test the boundaries. In the past, during various government crackdowns on markets, officials enforced a dress code for female traders - for example, requiring women to wear long skirts and not trousers (Good Friends, 2009). The media has made much of North Korea's "fashion police", actually voluntary members of the government-run Kim Il Sung Socialist Youth League (The Guardian, 24 April 2014). However, for the younger generation it is more likely that they must contend with the dress code enforcers of young people everywhere: the older generation and parents. "Lim" noted that: "My mother didn't like me wearing those kinds of revealing clothing"; and, according to "Kang", "I could never get away with wearing a short skirt in my little village". Here, Kang was referring to older women in her neighbourhood, not to state officials. ${ }^{4}$

Although there are social pressures to wear modest dress, there are equally strong social pressures to look "fashionable", which in North Korea means to look hyper-feminine. For the younger interviewees it became clear not only that casual dress was viewed as provincial, backward, unmodern and unfeminine, but that looking fashionable was worth the risk of older people's censure. Joo's story is interesting in this regard:

A long time ago, women didn't wear so much make-up, but now, make-up is applied thickly. I wondered why the trend became so, especially among people who traded in the markets. Especially those who sold vegetables. If you ask why, they say that if they do not wear pretty clothes and do make-up, their products do not sell. So they apply make-up thickly. Such heavy make-up on North Korean women these days. 
"Paik's" way of describing her decision to dye her hair conveys a sense of daring and also shows how women draw on Ri Sol-ju's image to justify their fashion choices:

Last year [2014], they used to inspect everybody wearing earrings. But then Ri Sol-ju appeared wearing earrings, and now the authorities can't do much about it... People started getting a little rebellious. In North Korea, dyeing hair is not allowed. But I did it... These days, a lot of people dye their hair. Not all of them. Mostly 30-something housewives, just a little.

"Kyung" said that dressing "prettily" even helped to minimise official harassment:

Because people began making money since the famine, they came to care more about clothes and appearance. Even if there are inspections every day while sitting at the markets, people are treated with less abuse if they are dressed prettily.

Comparing such remarks to those relating to earlier eras, which suggested that women preferred to wear functional clothing and that fashion was not typically a preoccupation, it seems clear that the Kim Jong Un period has ushered in a new fashion phenomenon: one where women are more openly concerned with fashion and more willing to push the boundaries in their fashion choices. What is noteworthy is the depth of women's commitment to this endeavour. None of our interviewees were rich, yet they were eager to spend what little money they had on cosmetics, high heels and bright clothes, even though such outfits were unsuitable for the physical demands of their daily life, which involved walking long distances, running market stalls and doing most, if not all, of the housework. Cvajner (2011) describes this as "beauty-as-effort", a shared understanding among women that the key to success is to pursue the feminine ideal. As she notes, such effort and displays of hyper-femininity actually improve a woman's prospects as a prospective partner, wife and mother, providing "the best proof of their moral standing, thus making them perfect candidates for such roles" (Cvajner, 2011, p. 367). We believe that this insight is also applicable to the hyper-feminine women of North Korea and their agentic mode of dressing for social success.

\section{Conclusion}

Huisman and Hondagneu-Sotelo (2005, p. 45) argue that "dress communicates identity" and "agentic processes", and as such can be seen to debunk the notion that women are either "passive victims" or "unrestricted agents". Indeed, recent developments in the social construction of femininity in North Korea suggest that the relationship between market participation and female empowerment is complex. Over three distinct, but overlapping, periods of change in the North Korean economy, women first participated in and then began to lead the economy through the establishment of markets. This female-led marketisation laid the foundation for the development of a quasi-capitalist economy, as well as creating a more capitalistic and materialistic society in which status is no longer prescribed by the state, but is tied to success in the market.

In this dynamic setting, North Korean women are negotiating and creating new sets of social expectations and constructions of femininity. Narrowly conceived domestic ideals of women as wives and mothers have become contested. Women are now at the forefront of practising capitalism and spreading capitalist culture, particularly through their fashion choices. Many 
women have now come to express their femininity through conspicuous consumption and have come to play a key role in contemporary status reproduction.

Female fashion reveals something of the relationship between a female's body and the society in which that body finds itself, and how this body is made acceptable in that society. While conforming to patriarchal versions of femininity, women are informed and active agents in a social process of constructing a new, distinctly North Korean, version of the ideal hyperfeminine woman. The performance of the complex quality of femininity is a crucial part, not just of the lives of women, but of the social dynamic of North Korea's quasicapitalism. Contrary to the dominant discourse of North Korean women as victims, we find that many contemporary North Korean women are fashioning their dress in an agentic process whereby they negotiate multiple sets of expectations. These expectations include those relating to tradition, nation and ideology, and those of modern and transforming standards of beauty, self-presentation and care, all in a quest to secure social status and success.

\section{Funding}

This work was supported by the Australian Research Council under Grant DP130101700

\section{References}

Anderson, A. (2016). Mothers and labourers: North Korea's gendered labour force in Women in Korea. Journal of History and Cultures, 6, 14-36. Retrieved from https://historyandcultures.files.wordpress.com/2016/02/anderson.pdf

Bordo, S. (2003). Unbearable weight: Feminism, western culture, and the body $\left(10^{\text {th }}\right.$ anniversary ed.). Berkeley: University of California Press.

Burton, A. M. (1992). The white woman's burden: British feminists and "the Indian woman" 1865-1915. In N Chaudhuri \& M. Strobel (Eds.), Western women and imperialism (pp. 137-157). Bloomington: Indiana University Press.

Cha, V. D. (2012). The impossible state: North Korea, past and future. London: Vintage Books.

Choo, H. Y. (2006). Gendered modernity and ethnicized citizenship: North Korean settlers in contemporary South Korea. Gender \& Society, 20(5), 576-604. doi:10.1177/0891243206291412

Cohen, G. A. (1978). Karl Marx's theory of history: A defence. Oxford: Clarendon Press.

Cvajner, M. (2011). Hyper-femininity as decency: Beauty, womanhood and respect in emigration. Ethnography, 12(3), 356-374. doi:10.1177/1466138110392463

De Beauvoir, S. (1952). The second sex. New York: Vintage Books.

Delamont, S. (1978). The contradictions in ladies' education. In S. Delamont \& L. Duffin (Eds.), The nineteenth-century woman: Her cultural and physical world (pp. 134-163). London: Croom Helm.

Entwistle, J. (2001). The dressed body. In J. Entwistle \& E. Wilson (Eds.), Body dressing (pp. 33-58). New York: Berg

Fifield, A. (2016, 14 May). North Korea's one-percenters savor life in "Pyonghattan". The Washington Post. Retrieved from https://www.washingtonpost.com/world/asia_pacific/north-koreas-one-percenterssavor-life-in-pyonghattan/2016/05/14/9f3b47ea-15fa-11e6-971adadf9ab18869_story.html 
Gal, S., \& Kligman, G. (2000). The politics of gender after socialism. Princeton, NJ: Princeton University Press.

Good Friends. (2009). No. 285: Women not wearing skirts under control with regulation during 150-Day Battle. North Korea Today. Retrieved from http://goodfriendsusa.blogspot.com.au/

Haggard, S., \& Noland, M. (2005). Hunger and human rights: The politics of famine in North Korea. Washington, DC: US Committee for Human Rights in North Korea.

Haggard, S., \& Noland, M. (2007). Famine in North Korea: Markets, aid, and reform. New York: Columbia University Press.

Haggard, S., \& Noland, M. (2012). Economic Crime and Punishment in North Korea. Political Science Quarterly, 127(4), 659-683. doi:10.1002/j.1538-165X.2012.tb01131.x

Haggard, S., \& Noland, M. (2013). Gender in transition: The case of North Korea. World Development, 41, 51-66. doi:10.1016/j.worlddev.2012.06.012

Huisman, K., \& P Hondagneu-Sotelo, P. (2005). Dress matters: Change and continuity in the dress practices of Bosnian Muslim refugee women. Gender \& Society, 19(1), 44-65. doi: $10.1177 / 0891243204269716$

Hunter, H. (1999). Kim Il-song's North Korea. Westport, CT: Praeger.

Jung, K., \& Dalton, B. (2006). Rhetoric versus reality for the women of North Korea. Asian Survey, 46(5), 741-760. doi:10.1525/as.2006.46.5.741

Kang, D., \& Park, J. (2011). Hanryu, Bukhaneul Heundeulda [Korean wave stirs North Korea]. Seoul: Neulpulm.

Kim, C. H. (2014). North Korea's vinalon city: Industrialism as socialist everyday life. Positions, 22(4), 809-836. doi:10.1215/10679847-2793197

Kim, I-. S. (1946). Congratulations on the founding of the magazine, Korean women, 6 September 1946. Kim Il Sung works, Vol. 2. Pyongyang: Foreign Language Publishing House.

Kim, I-. S. (1971). The duty of mothers in the education of children: Speech at the national meeting of mothers, 16 November 1961. On the work of the Women's Union. Pyongyang: Foreign Languages Publishing House.

Kim, I-. S. (1989, May). Women should be feminine. Joseon Nyeoseong (North Korean Women [Magazine]).

Kim, S.-Y. (2011). Dressed to kill: Women's fashion and body politics in North Korean visual culture. Positions: East Asia Cultural Critique, 19(1), 159-192. Retrieved from muse.jhu.edu/article/444424

Kim, S. (2013). Everyday life in the North Korean revolution, 1945-1950. Ithaca, NY: Cornell University Press.

Langland, E. (1995). Nobody's angels: Middle-class women and domestic ideology in Victorian culture. London: Cornell University Press.

Lankov, A. (2014). The real North Korea: Life and politics in the failed Stalinist utopia. Oxford: Oxford University Press.

Lankov, A. (2015). N. Korea's quiet market reforms. Retrieved from https://www.nknews.org/2015/09/n-koreas-quiet-market-reforms/

Lankov, A., \& Kim, S. H. (2008). North Korean market vendors: The rise of grassroots capitalists in a post-Stalinist society, Pacific Affairs, 81(1) 53-76. Retrieved from http://www.pacificaffairs.ubc.ca/files/2011/10/article_sample_2.pdf

Lankov, A., \& Kim, S. H. (2014). Useless men, entrepreneurial women, and North Korea's post-socialism: Transformation of gender roles since the early 1990s. Asian Journal of Women's Studies, 20(2), 68-96. doi:10.1080/12259276.2014.11666182 
Lee, M. (2005). The issue of North Korean women by examining gender awareness of female defectors. The Korean Journal of International Relations, 45(5), 155-175. Retrieved from http://kaisnet.or.kr/resource/down/3_07.pdf

Lim, S. H. (2004). Siklyangnankwa Bukhan yeoseongeui yeokhal mit euisik byeonhwa [Change in the role and consciousness of North Korean women after the food crisis]. Seoul: Korea Institute for National Unification.

Lintner, B. (2007, 25 July). North Korea's living exports. Asia Times. Retrieved from http://www.nkeconwatch.com/2007/07/25/north-koreas-living-exports/

Muico, N. K. (2005). An absence of choice: The sexual exploitation of North Korean women in China. Anti-Slavery International. Retrieved from http://www.antislavery.org/homepage/resources/PDF/Full\%20Korea\%20report\%20200 5.pdf.

Natsios, A. (2010). The great North Korean famine. Washington, DC: US Institute for Peace.

Oh, K., \& Hassig, R. C. (2004). North Korea through the looking glass. Washington, DC: Brookings Institution Press.

Praechter, C. (2006). Masculine femininities/feminine masculinities: Power, identities and gender. Gender and Education, 18(3), 253-263. doi:10.1080/09540250600667785

Radio Free Asia. (2013). North Korea's designer knockoff industry cranks out "Ri Sol Ju Style". Retrieved from http://www.rfa.org/english/news/korea/fashion08272013160737.html

Ryang, S. (2000). Gender in oblivion: Women in the Democratic People's Republic of Korea (North Korea). Journal of Asian and African Studies, 35(3), 323-349. doi:10.1163/156852100512275

Seidman, S. (2005). Theoretical perspectives. In S. Seidman, N. Fisher \& C. Meeks (Eds.), Handbook of the new sexuality studies (pp. 3-13). New York: Routledge.

Silberstein, B. K. (2015). Growth and geography of markets in North Korea: New evidence from satellite imagery, US-Korea Institute at SAIS. Retrieved from http://uskoreainstitute.org/wp-content/uploads/2015/10/USKI-New-Voices-BKSMarkets-Oct2015.pdf

Smith, H. (2015). North Korea: Markets and military rule. Cambridge: Cambridge University Press.

Teng, J. E. (1996). The construction of the "traditional Chinese woman" in the Western academy: A critical review. Signs: Journal of Women in Culture and Society, 22(1), 115-151. Retrieved from http://www.jstor.org/stable/3175043

The Guardian (2014, 24 April). North Korea's fashion police. Retrieved from https://www.theguardian.com/world/2014/apr/24/north-korea-fashion-police

Tudor, D., \& Pearson, J. (2015). North Korea confidential: Private markets, fashion trends, prison camps, dissenters and defectors. North Clarendon, VT: Tuttle Publishing.

Tyner, K. E., \& Ogle, J. P. (2009). Feminist theory of the dressed female body. Clothing and Textiles Research Journal, 27(2), 98-121. doi:10.1177/0887302X08322715

\footnotetext{
Notes

${ }^{1}$ These trips to North Korea were planned as part of an Australian Research Council funded project. We concede the limitations involved when taking trips to North Korea, and non-participant observation and note-taking were conducted with the intention that these be used only as supplementary data to inform the findings of our interviews.

${ }^{2}$ Although a very small number of North Korea's elite dressed in foreign couture during earlier periods, this never represented a fashion "trend". This and other "decadent" tastes were largely indulged in private, and often among elite North Koreans living overseas. They were thus part of the secret world of the Kims and their inner circle that was never aired in public.
} 
${ }^{3}$ For more photographs of this style see the Tongil Tours website: http://tongiltours.com/north-korea-tours/ ${ }^{4}$ This aligns with the findings of Huisman and Hondagneu-Sotelo (2005, p. 49), who found that the dress codes of Bosnian refugees in Vermont were typically enforced (and reinforced) by the disapproval of older women in the community of less conventional styles. 